\title{
COMPARATIVE EVALUATION OF THE SUSCEPTIBILITY OF CULTIVATED FISHES TO THE NATURAL INFECTION WITH MYXOSPOREAN PARASITES AND TISSUE CHANGES IN THE HOST
}

\author{
MARTINS, M. L., ${ }^{1}$ SOUZA, V. N. de, ${ }^{1}$ MORAES, J. R. E. de, ${ }^{2}$ \\ MORAES, F. R. de ${ }^{1,2}$ and COSTA, A. J. da ${ }^{2}$ \\ ${ }^{1}$ Centro de Aqüicultura, UNESP, Rodovia Carlos Tonanni, km 5, CEP 14870-000, Jaboticabal, SP, Brazil \\ ${ }^{2}$ Departamento de Patologia Veterinária, Faculdade de Ciências Agrárias e Veterinárias, UNESP, Rod. Carlos \\ Tonanni, km 5, CEP 14870-000, Jaboticabal, SP, Brazil \\ Correspondence to: Maurício Laterça Martins, Centro de Aqüicultura, UNESP, Rodovia Carlos Tonanni, km 5, \\ CEP 14870-000, Jaboticabal, SP, Brazil, e-mail: mlaterça@caunesp.unesp.br \\ Received November 04, 1997 - Accepted November 17, 1998 - Distributed June 30, 1999
}

(With 1 figure)

\begin{abstract}
The purpose of the study was to evaluate the susceptibility of 4 important cultivated fishes to sporozoan parasites. Fishes were collected bimonthly from a pond for a period of 1 year. Myxobolus colossomatis and Henneguya piaractus were found in the internal organs and gills, respectively. The combined incidence of parasitism by both myxozoa was $97.3 \%$ in pacu (Piaractus mesopotamicus), $33.3 \%$ in hybrid tambacu (Piaractus mesopotamicus x Colossoma macropomum), 5.6\% in tambaqui (Colossoma macropomum) and 0\% in carp (Cyprinus carpio). Pacu was the most susceptible fish and was parasitized $79.2 \%$ in the gills, $66.7 \%$ in the kidney and $50 \%$ in the spleen. Histopathological evaluation of the gills showed hemorrhages, inflammatory reaction with mononuclear cells and fibroblasts and hyperplasia of basal and goblet cells.
\end{abstract}

Key words: Myxozoa, susceptibility, histopathology, cultivated fish.

\section{RESUMO}

\section{Avaliação comparativa da susceptibilidade de peixes cultivados à infecção natural com} parasitos mixosporídeos e alterações teciduais no hospedeiro

O objetivo deste estudo foi avaliar a susceptibilidade de 4 importantes peixes cultivados a parasitos esporozoários. Os peixes foram coletados bimestralmente de um tanque de cultivo, durante 1 ano. Myxobolus colossomatis e Henneguya piaractus foram encontrados nos órgãos internos e brânquias, respectivamente. A incidência de ambos os parasitos foi de 97,3\% em pacu (Piaractus mesopotamicus), 33,3\% no híbrido tambacu (Piaractus mesopotamicus x Colossoma macropomum), 5,6\% em tambaqui (Colossoma macropomum) e 0\% em carpa (Cyprinus carpio). Pacu foi o peixe mais susceptível, encontrando-se parasitado $79,2 \%$ nas brânquias, $66,7 \%$ nos rins e $50 \%$ no baço. A análise histopatológica das brânquias mostrou hemorragias, reação inflamatória com células mononucleares, fibroblastos e hiperplasia das células basais e mucosas.

Palavras-chave: Myxozoa, susceptibilidade, histopatologia, peixes cultivados. 


\section{INTRODUCTION}

Myxosporidiosis is an infectious disease caused by myxosporean of the Phylum Myxozoa, Class Myxosporea and Order Bivalvulida. Poor water quality and handling stress predisposes cultivated fishes to sporozoan infection in Brazil and in the other countries (Lom \& Noble, 1984; Martins et al., 1997).

Several species of Henneguya infecting fish have been described in Brazil (Pinto, 1928; Guimarães \& Bergamin, 1933; Cordeiro et al., 1983/1984; Gioia et al., 1986; Azevedo \& Matos, 1989; Rocha et al., 1992; Torres et al., 1994; Azevedo \& Matos, 1995, 1996; Gioia \& Cordeiro, 1996; Martins \& Souza, 1997; Casal et al., 1997).

Myxobolus spp from the gills and internal organs have also been described by Pinto (1928), Walliker (1969), Molnár \& Békési (1993) and Casal et al. (1996).

The majority of the published works in Brazil are taxonomic studies but no information exists on the susceptibility of the host species or on the pathology associated with these sporozoan. Ichthyopathological studies in 6 fishfarms situated in the Ceará State, were related by Békési (1992), in a period of 1987 to 1990 . The author reported the occurrence of Henneguya and Myxobolus, among other parasites.

In the present work the authors studied the natural susceptibility of pacu (Piaractus mesopotamicus Holmberg, 1887), tambaqui (Colossoma macropomum Cuvier, 1818), tambacu (a hybrid between P. mesopotamicus female and C. macropomum male) and carp (Cyprinus carpio Linnaeus, 1758 ) to the myxosporean in natural infections. Determination of incidence and histopathological studies were performed.

\section{MATERIAL AND METHODS}

\section{Fishes}

Pacu (P. mesopotamicus Holmberg, 1887), tambaqui (C. macropomum Cuvier, 1818), carp (C. carpio Linnaeus, 1758) and tambacu (hibrid of $P$. mesopotamicus female with C. macropomum male), were collected bimonthly, from a $3,500 \mathrm{~m}^{2}$ pond. Fish were maintained in $1,000 \mathrm{~L}$ aquarium until samples.

\section{Histopathological analysis and myxosporidian spores observation}

Small pieces of liver, kidney, spleen and gills were squeezed between a glass microscope slide and a coverslip to obtain a smear. Wet mounts of the smear were examined microscopically and when parasites were found, the smears were air dried at room temperature, fixed in methylic alcohol, stained in 1:9 Giemsa's solution for $10 \mathrm{~min}$. (Meyers et al., 1977, slightly modified) and mounted in synthetic Canadian balsam.

These slides were then used to identify parasites following the recomendations of Lom \& Arthur (1989). Parasitized tissue were fixed in 10\% buffered formalin and embedded in paraffin-block, sectioned $(6 \mu \mathrm{m})$ and stained in haematoxylin-eosin, periodic acid of Shiff or Masson trichrome.

\section{Water quality}

Water quality was monthly measured according to Golterman et al. (1978) with the aid of Van Dorn bottle in a $0.3 \mathrm{~m}$ depth. Dissolved oxygen (Winkler method), pH (Quimis phmeter), temperature, electric conductivity (conductimeter MethromHerisau E-527) and total alkalinity, were measured. The samples were collected and measured at 9:00 hours.

\section{RESULTS}

\section{Parasitological analysis}

Parasitological analysis revealed the presence of Myxobolus colossomatis Molnár \& Békési, 1993 in the kidney, liver, spleen, muscle and gall bladder of Pacu. The same species was observed in the kidney of C. macropomum. Henneguya piaractus Martins \& Souza, 1997 was observed in the gills of pacu, tambaqui and tambacu. In carp the presence of myxosporean protozoan was not observed. Specific identification of the parasites was performed according to Lom \& Arthur (1989) and Martins \& Souza (1997).

\section{Susceptibility of fishes to myxosporean}

Thirty 7 pacu (average standard length 22.6 $\mathrm{cm}), 8$ tambaqui (average standard length $31.2 \mathrm{~cm}$ ), 6 tambacu (average standard length $33.5 \mathrm{~cm}$ ) and 36 carp (average standard length $23.4 \mathrm{~cm}$ ), were necropsied. Table 1 presents incidence of parasitism in the different host and samples collected. 
TABLE 1

Prevalence of myxosporean in the different hosts during February, 1995 to February, 1996.

\begin{tabular}{|c|c|c|c|c|}
\hline Month & Fish & Number of fishes necropsied & Infected fishes & Prevalence $(\%)$ \\
\hline February & $\begin{array}{l}\text { C. carpio } \\
\text { P. mesopotamicus } \\
\text { Tambacu } \\
\text { C. macropomum }\end{array}$ & $\begin{array}{l}- \\
12 \\
- \\
2\end{array}$ & $\begin{array}{l}- \\
12 \\
- \\
0\end{array}$ & $\begin{array}{c}- \\
100 \\
- \\
0\end{array}$ \\
\hline April & $\begin{array}{l}\text { C. carpio } \\
\text { P. mesopotamicus } \\
\text { Tambacu } \\
\text { C. macropomum }\end{array}$ & $\begin{array}{c}11 \\
10 \\
2 \\
-\end{array}$ & $\begin{array}{l}0 \\
10 \\
2 \\
-\end{array}$ & $\begin{array}{c}0 \\
100 \\
100 \\
-\end{array}$ \\
\hline June & $\begin{array}{l}\text { C. carpio } \\
\text { P. mesopotamicus } \\
\text { Tambacu } \\
\text { C. macropomum }\end{array}$ & $\begin{array}{l}5 \\
2 \\
- \\
8\end{array}$ & $\begin{array}{l}0 \\
2 \\
- \\
1\end{array}$ & $\begin{array}{c}0 \\
100 \\
- \\
12.5\end{array}$ \\
\hline August & $\begin{array}{l}\text { C. carpio } \\
\text { P. mesopotamicus } \\
\text { Tambacu } \\
\text { C. тасropomum }\end{array}$ & $\begin{array}{l}11 \\
5 \\
- \\
-\end{array}$ & $\begin{array}{l}0 \\
5 \\
- \\
-\end{array}$ & $\begin{array}{c}0 \\
100 \\
- \\
-\end{array}$ \\
\hline October & $\begin{array}{l}\text { C. carpio } \\
\text { P. mesopotamicus } \\
\text { Tambacu } \\
\text { C. тасropomum }\end{array}$ & $\begin{array}{l}2 \\
2 \\
- \\
2\end{array}$ & $\begin{array}{l}0 \\
2 \\
- \\
0\end{array}$ & $\begin{array}{c}0 \\
100 \\
- \\
0\end{array}$ \\
\hline December & $\begin{array}{l}\text { C. carpio } \\
\text { P. mesopotamicus } \\
\text { Tambacu } \\
\text { C. тасropoтиm }\end{array}$ & $\begin{array}{l}3 \\
4 \\
4 \\
4\end{array}$ & $\begin{array}{l}0 \\
3 \\
0 \\
0\end{array}$ & $\begin{array}{c}0 \\
75 \\
0 \\
0\end{array}$ \\
\hline February & $\begin{array}{l}\text { C. carpio } \\
\text { P. mesopotamicus } \\
\text { Tambacu } \\
\text { C. macropomum } \\
\end{array}$ & $\begin{array}{l}4 \\
2 \\
- \\
2 \\
\end{array}$ & $\begin{array}{l}0 \\
2 \\
- \\
0\end{array}$ & $\begin{array}{c}0 \\
100 \\
- \\
0 \\
\end{array}$ \\
\hline Total & $\begin{array}{l}\text { C. carpio } \\
\text { P. mesopotamicus } \\
\text { Tambacu } \\
\text { C. тасropoтum }\end{array}$ & $\begin{array}{c}36 \\
37 \\
6 \\
18\end{array}$ & $\begin{array}{c}0 \\
36 \\
2 \\
1\end{array}$ & $\begin{array}{c}0 \\
97.3 \\
33.3 \\
5.6\end{array}$ \\
\hline
\end{tabular}

Pacu were $100 \%$ infected for all months, except in December when they were only observed $75 \%$ of the fishes.

Thus, a total of $97.3 \%$ of pacu were infected by $H$. piaractus and $M$. colossomatis followed by $33.3 \%$ of tambacu hybrid, $5.7 \%$ of tambaqui and $0.0 \%$ of carp.

The incidence of parasitized tissues in the pacu was: gills $(79.2 \%)$, kidney $(66.7 \%)$, spleen (50\%), heart (20.8\%) and muscle (16.7\%). Liver and gonads showed $12.5 \%$ infection, eyes $(8.3 \%)$ and swim bladder and brain (4.2\%) (Fig. 1a). One hundred percent of the tambacu had parasitized gills and 50\% had parasitized kidneys and spleens (Fig. 1b). In tambaqui, H. piaractus spores were present in all the gills (Fig. 1c). Grossly, cysts measuring 0.1 to $0.5 \mathrm{~mm}$ diameter throughout the gill filament were observed. Sometimes, cysts and associated hemorrhage were observed throughout the entire length of the primary lamellae. Six out of 37 pacu had pale livers, spleens and kidneys.

\section{Histopathological analysis}

Hemorrhages were observed in the most intense infections. Cysts were surrounded by 2 layers of elongate fibroblast-like cells and an inflammatory mononuclear infiltrate.

Larger cysts displaced the adjacent lamellae. Hyperplasia of the basal cells and displacement of the respiratory epithelium was observed. Sometimes sub-epithelial edema with displacement of the gill epithelium and congestion of the sinusoid capillary, was observed.

Hyperplasia of the goblet cells at the end of the secondary lamellae, was frequently observed as well. 

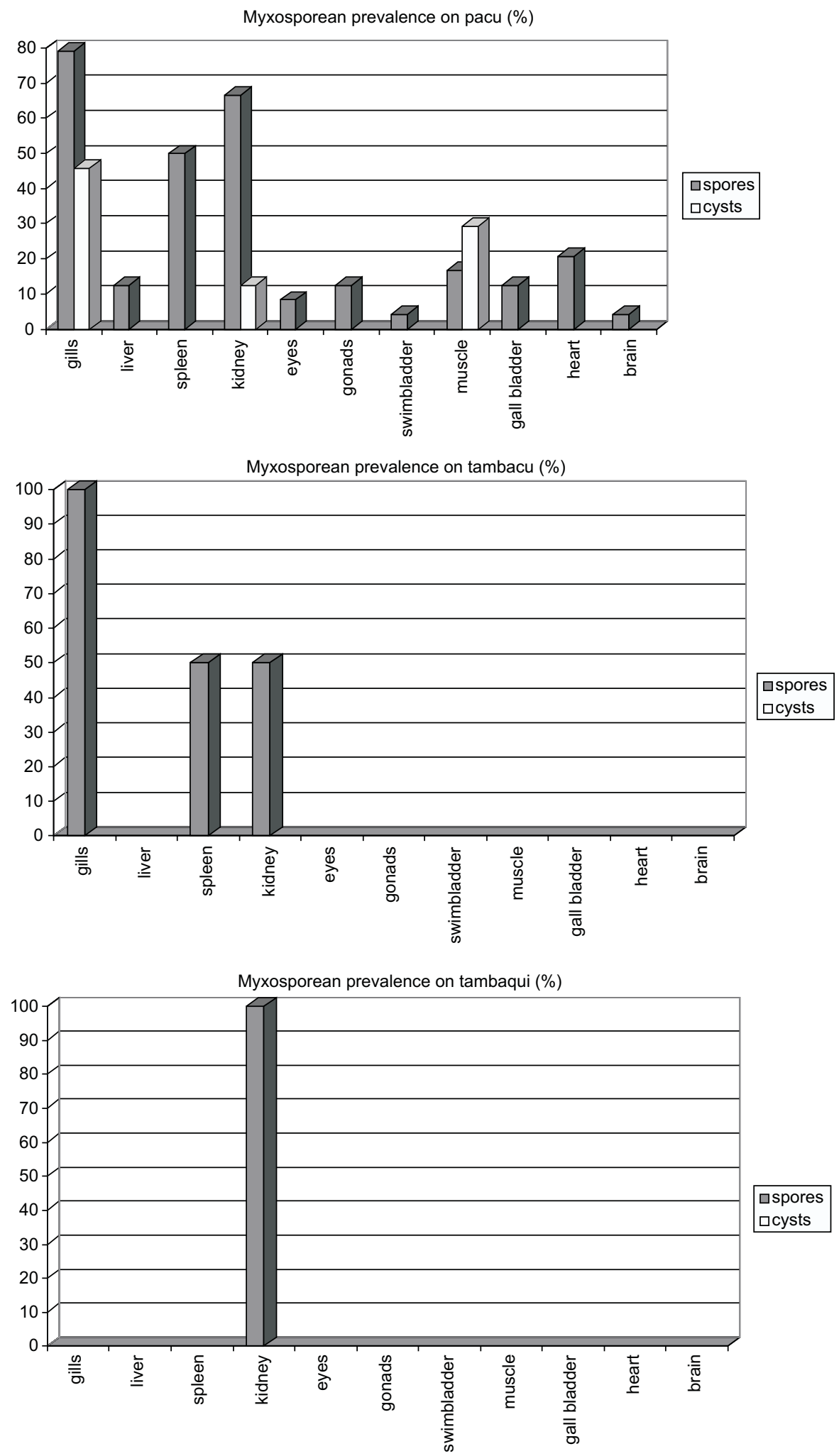

Fig. 1 - Prevalence of myxosporeans found in the tissues of infected fish. 
In the liver of pacu an accumulation of spores with evident polar capsules identified as $M$. colossomatis were observed. In these cases it was not possible to detect the presence of the cystic membrane and the host response was slight with rare thrombocytes surrounding the spores.

\section{Water quality}

Water quality (Table 2) showed $\mathrm{pH}$ slightly acid, without significant changes, except in the day 26th of January. Throughout the course of the analysis, dissolved oxygen was 2.8 to $6.5 \mathrm{mg} / \mathrm{l}$. Temperature values in May through October were 20 to $21.5^{\circ} \mathrm{C}$. For the period November-February temperature were $25 \pm 2^{\circ} \mathrm{C}$. Conductivity was 31.6 to $60.0 \mathrm{mS} . \mathrm{cm}^{-1}$ and alkalinity 17.6 to $24.6 \mathrm{mg} / \mathrm{l}$.

\section{DISCUSSION}

Present results showed that carp were not susceptible to myxosporean parasites. In the studied fishes, pacu was the most susceptible and the myxosporean were observed in $97.3 \%$ of them. It must be emphasized that 6 out of 7 collected samples presented $100 \%$ of infection with the $H$. piaractus and $M$. colossomatis. In this kind of fish, gills, kidney and spleen were the most parasitized organs. Tambaqui and tambacu presented intermediate susceptibility $5.6 \%$ and $33.3 \%$, respectively. The interesting result is the intermediate prevalence of tambacu compared to their ancestry pacu and tambaqui. Moreover, the frequency of parasitized organs was always higher in pacu than in the others. Tambacu presented $16.7 \%$ prevalence in the spleen and kidney. In tambaqui the spores were present in $5.6 \%$ of examined kidney. Comparative studies of the fish susceptibility to myxosporean are rare in the literature and the common finding is prevalence of parasites in the fish. Moser \& Love (1975) related $50 \%$ of prevalence of $H$. sebasta in Sebastes serranoides. In carp $95 \%$ of the old fishes were infected (Molnár \& Kovács-Gayer, 1985).

TABLE 2

Water analysis of fish pond situated at Aquaculture Center, UNESP, Jaboticabal, SP.

\begin{tabular}{|c|c|c|c|c|c|}
\hline & PH & $\mathrm{O}_{2}(\mathrm{mg} / \mathrm{L})$ & $\mathbf{T}\left({ }^{\circ} \mathbf{C}\right)$ & Cond. $\left({ }_{\mu} S . \mathrm{cm}^{-1}\right)$ & Alcal. (mg/L) \\
\hline $31 / 05 / 95$ & 6.8 & 2.8 & 21.5 & 50 & 21.1 \\
\hline $23 / 06 / 95$ & 6.8 & 3.4 & 20 & 60 & 22 \\
\hline $31 / 07 / 95$ & 6.7 & 5.8 & 20 & 41 & 20.5 \\
\hline $31 / 08 / 95$ & 6.7 & 6.5 & 21 & 34 & 17.6 \\
\hline 28/09/95 & 6.6 & 4.4 & 21 & 31.6 & 18.5 \\
\hline $23 / 10 / 95$ & 6.4 & 3 & 21 & 43.6 & 17.6 \\
\hline $30 / 11 / 95$ & 6.8 & 3.3 & 25 & 37.6 & 18.5 \\
\hline $29 / 12 / 95$ & 6.7 & 3.1 & 24.5 & 43.6 & 24.6 \\
\hline $26 / 01 / 96$ & 7.3 & 4.1 & 27 & 43.6 & 17.6 \\
\hline $28 / 02 / 96$ & 6.4 & 4.6 & 26 & 46.5 & 17.6 \\
\hline
\end{tabular}

The infection percentage of Henneguya in Pomatomus saltatrix was $24 \%$ to $57 \%$, for a period of 3 years (Meyers et al., 1977).

In lambari (Hyphessobrycon anisitsi) myxosporean prevalence was $20 \%$ (Cordeiro et al., 1983/84) and $6.7 \%$ in traíra (Hoplias malabaricus) (Azevedo \& Matos, 1996). Dana (1990) observed myxosporean prevalence in common carp reared at different temperatures. At $25^{\circ} \mathrm{C}$ the prevalence was higher $(70 \%)$ than at $31^{\circ} \mathrm{C}(53.3 \%)$.
In the North of Brazil, Molnár \& Békési (1993) related $100 \%$ of infection in tambaqui with 2 to $14 \mathrm{~cm}$ length. The authors identified the parasites as $M$. colossomatis in the different organs. By the way, Békési (1992) related the occurrence of Ichthyophthirius, Henneguya and Myxobolus, during the period of 1987 to 1990 . The author commented that myxosporean infection provoked no mortality, but Ichthyophthirius, Chilodonella and monogenean usually caused mortality. The 
effects of the parasitism in Brazilian fishes from several fishfarms from Jaboticabal (SP), were analyzed in the Aquaculture Center, UNESP, where Martins \& Romero (1996) observed 15.3\% Henneguya infection of pacu and 2.2\% Henneguya infection of tambacu. Martins et al. (1997) reported a severe outbreak of Henneguya sp infection in cultivated pacu. All (100\%) of the fishes in a pond died.

Histopathological study of the gills showed that the lesions caused were related to the infection degree. A few number of cysts and parasites in the gills with a slight hyperplasia of the basal cells and goblet cells of the epithelium associated or not to congestion was observed. Severe infection caused hyperplasia of the basal and goblet cells and increase in the mucus production. In these cases, the inflammatory infiltrate was severe with the presence of fibroblast-like cells, mononuclear cells, congestion and subepithelial edema. The inter and intralamellar presence of cysts, associated to hyperplasia and inflammation increased the adherence between secondary lamellae. This fact and the hyperplasia of the goblet cells associated with an increase in the mucus production caused respiratory distress syndrome and suffocation of fishes (Dyková \& Lom, 1978; Current \& Janovy, 1978; Shariff, 1982; Bowser \& Conroy, 1985; Kalavati \& Narasimhamurti, 1985; Martins et al., 1997). The lesions were similar to those observed in H. psorospermica infections in perch, Perca fluviatilis (Dyková \& Lom, 1978).

In the present work, the accumulation of the Myxobolus spores in the liver of the P. mesopotamicus cause no changes in the host, except a discreet presence of thrombocytes surrounding the spores. Some authors described severe lesions caused by Myxobolus in carp, involving necrosis and gut degeneration (Molnár \& Kovács-Gayer, 1985; Dyková \& Lom, 1988). However, the presence of Myxobolus in the internal organs may cause or not disease. Probably this variation is related to the host response and parasite species involved.

According to the analyzed data the water quality does not interfere with the prevalence of the studied parasites. It is necessary to emphasize that fish ponds are a dynamic system with constant flow of water with a direct effect to the biotic and abiotic factors of the pond (Sipaúba-Tavares \& Colus, 1995). In the artificial system of little depth, blow wind is sufficient to provoke a complete mix in the water, preventing water stratification (Oliveira et al., 1992). Nevertheless, ground, morphometry, evaporation and precipitation processes, were mechanisms that affect the systems dynamics (Durigan et al., 1992; Sipaúba-Tavares \& Moreno, 1994; Sipaúba-Tavares \& Colus, 1995). In the present work, the values were in line with those observed by Sipaúba-Tavares et al. (1995) in a pond situated at Aquaculture Center, UNESP, Jaboticabal, SP.

Acknowledgements - The authors are indebted to Dra. Lúcia Helena Sipaúba-Tavares (Centro de Aqüicultura, UNESP, Jaboticabal, SP, Brasil) for the water analysis and suggestions.

\section{REFERENCES}

AZEVEDO, C. \& MATOS, E., 1989, Some ultrastructural data on the spore development in a Henneguya sp. parasite of the gill of a Brazilian fish. Parasitol. Res., 76: 131134.

AZEVEDO, C. \& MATOS E., 1995, Henneguya adherens n.sp. (Myxozoa: Myxosporea), parasite of the amazonian fish, Acestrorhynchus falcatus. J. Euk. Microbiol., 42(5): 515-518.

AZEVEDO, C. \& MATOS, E., 1996, Henneguya malabarica sp. nov. (Myxozoa: Myxobolidae) in the amazonian fish Hoplias malabaricus. Parasitol. Res., 82: 222-224.

BÉKÉSI, L., 1992, Evaluation on data of ichthyopathological analysis in the Brazilian northeast. J. Braz. Assoc. Adv. Sci., 44(6): 400-403.

BOWSER, P. R. \& CONROY, J. D., 1985, Histopathology of gill lesions in channel catfish associated with Henneguya. J. Wildl. Dis., 21(2): 177-179,

CASAL, G., MATOS, E. \& AZEVEDO, C., 1996, Ultrastructural data on the life cycle stages of Myxobolus braziliensis $\mathrm{n}$. sp. parasite of na amazonian fish. Eur. J. Protistol., 32: 123-127.

CASAl, G., MATOS, E. \& AZEVEDO, C., 1997, Some ultrastructural aspects of Henneguya striolata sp. nov. (Myxozoa: Myxosporea) a parasite of the Amazonian fish Serrasalmus striolatus. Parasitol. Res., 83: 93-95.

CORDEIRO, N. S., ARTIGAS, P. T., GIOIA, I. \& LIMA, R. S., 1983/1984. Henneguya pisciforme n. sp. mixosporídeo parasito de brânquias de lambari Hyphessobrycon anisitsi (Pisces: Characidae). Mem. Inst. Butantan, 47/ 48: 61-69.

CURRENT, W. L. \& JANOVY, J. JR., 1978, Comparative study of ultrastructure of interlamellar and intralamellar types of Henneguya exilis Kudo from channel catfish. $J$. Protozool., 25: 56-65.

DANA, D., 1990, An analysis of the effect of rearing temperature on the prevalence of myxosporea in experimentally infected common Carp (Cyprinus carpio L.). Asian Fish. Sci., 3: 329-335. 
DURIGAN, J. G., SIPAÚBA-TAVARES, L. H. \& OLIVEIRA, D. B. S., 1992, Estudo limnológico em tanques de piscicultura. Parte I: variação nictemeral de fatores físicos, químicos e biológicos. Acta Limnológica Brasileira, 4: 211-223.

DYKOVÁ, I. \& LOM, J., 1978, Histopathological changes in fish gills infected with myxosporidian parasites of the genus Henneguya. J. Fish Biol., 12: 197-202.

DYKOVÁ, I. \& LOM, J., 1988, Review of pathogenic myxosporeans in intensive culture of carp (Cyprinus carpio) in Europe. Folia Parasitologica, 35: 289-307.

GIOIA, I. \& CORDEIRO, N. S., 1996, Brazilian myxosporidians' check-list (Myxozoa). Acta Protozoologica, 35: 137-149.

GIOIA, I., CORDEIRO, N. S. \& ARTIGAS, P. T., 1986, Henneguya intracornea n. sp. (Myxozoa: Myxosporea) parasito do olho do lambari, Astyanax scabripinis (Jenyns, 1842) (Osteichthyes: Characidae). Mem. Inst. Oswaldo Cruz, 81: 401-407.

GOLTERMAN, H. L., CLYMO, R. S. \& OHNSTAD, M. A., 1978, Methods for physical and chemical analysis of freshwater. $2^{\text {a }}$ ed., Oxford: Blackwell Scientific, (JNP Handbook, 8), 213p.

GUIMARÃES, J. R. A. \& BERGAMIN, F., 1933, Considerações sobre ictioepizootias produzidas pelos mixosporídeos do gênero Henneguya Thélohan. Rev. Ind. Anim., 10: 1151-1156.

KALAVATI, C. \& NARASIMHAMURTI, C. C., 1985, Histopathological changes in the gills of Channa punctatus B1., Infected with Henneguya waltairensis. Arch. Protistenk., 129: 199-202.

LOM, J. \& ARTHUR, J. R., 1989, A guideline for the preparation of species descriptions in Myxosporea. J. Fish Dis., 12: 151-156.

LOM, J. \& NOBLE, E. R., 1984, Revised classification of the class Myxosporea Bütschli, 1881. Folia Parasitologica, 31: 193-205.

MARTINS, M. L. \& ROMERO, N. G., 1996, Efectos del parasitismo sobre el tejido branquial en peces cultivados: estudio parasitologico e histopatologico. Rev. Brasil. Zool., 13(2): 489-500.

MARTINS, M. L., SOUZA, V. N., MORAES, F. R., MORAES, J. R. E., COSTA, A. J. \& ROCHA, U. F., 1997, Pathology and behavioral effects associated with Henneguya sp. (Myxozoa: Myxobolidae) infections of captive pacu Piaractus mesopotamicus in Brazil. J. World Aquac. Soc., 28(2): 215-218.

MARTINS, M. L. \& SOUZA, V. N., 1997, Henneguya piaractus n.sp. (Myxozoa: Myxobolidae), a gill parasite of Piaractus mesopotamicus Holmberg, 1887 (Osteichthyes: Characidae). Rev. Brasil. Biol., 57(2): 239-245.
MEYERS, T. R., SAWYER, T. K. \& MACLEAN, S. A., 1977, Henneguya sp. (Cnidospora: Myxosporea) parasitic in the heart of the bluefish Pomatomus saltatrix. $J$. Parasitol., 63: 890-896.

MOLNÁR, K. \& BÉKÉSI, L., 1993, Description of a new myxobolus specie, M. colossomatis $\mathrm{n}$. $\mathrm{sp}$. from the teleost Colossoma macropomum of the Amazon River Basin. J. Appl. Ichthyol., 9: 57-63.

MOLNÁR, K. \& KOVÁCS-GAYER, E., 1985, The paghogenicity and development within the host fish of Myxobolus cyprini Doflein. Parasitology, 90: 549-555.

MOSER, M. \& LOVE, M. S., 1975, Henneguya sebasta sp. n. (Protozoa, Myxosporidia) from California rockfish, Sebastes spp. J. Parasitol., 61(3): 481-483.

OLIVEIRA, D. B. S., SIPAÚBA-TAVARES, L. H. \& DURIGAN, J. G., 1992, Estudo limnológico em tanques de piscicultura. Parte II: variação semanal de fatores físicos, químicos e biológicos. Acta Limnológica Brasileira, 4: 123-137.

PINTO, C., 1928, Myxosporídeos e outros protozoários intestinais de peixes observados na América do Sul. Arch. Inst. Biol., 1: 101-126.

ROCHA, E., MATOS, E. \& AZEVEDO, C., 1992, Henneguya amazonica n. sp. (Myxozoa, Myxobolidae), parasitizing the gills of Crenicichla lepidota Heckel, 1840 (Teleostei, Cichlidae) from Amazon River. Eur. J. Protistol. 28: 273278.

SHARIFF, M., 1982, Henneguya shaharini sp. n. (Protozoa: Myxozoa), a parasite of marble goby, Oxyleotris marmoratus Bleeker. J. Fish Dis., 5: 37-45.

SIPAÚBA-TAVARES, L. H. \& COLUS, D. S. O., 1995, Estudo da variação nictemeral em um viveiro de piscicultura no período da seca. Rev. Unimar, 17(2): 225-236.

SIPAÚBA-TAVARES, L. H., LIGEIRO, S. R. \& DURIGAN, J. G., 1995, Variação de alguns parâmetros limnológicos em um viveiro de piscicultura em função da luz. Acta Limnológica Brasileira, 7: 138-150.

SIPAÚBA-TAVARES, L. H. \& MORENO, S. Q., 1994, Variação dos parâmetros limnológicos em um viveiro de piscicultura nos períodos da seca e chuva. Rev. Unimar, 16(4): 229-242.

TORRES, A., MATOS, E. \& AZEVEDO, C., 1994, Fine structure of Henneguya amazonica (Myxozoa) in ovarian follicles of Hoplosternum littorale (Teleostei) from the Amazon River. Dis. Aquat. Org., 19: 169-172.

WALLIKER, D., 1969, Myxosporidea of some Brazilian freshwater fishes. J. Parasitol., 55(5): 942-948. 